\title{
College Libraries Versus the Rising Tide
}

W

E HEAR that college and university libraries are going to be swamped by the demands made on them by the rising tide of collegians. "Buildings which in many cases are already inadequate will become even more crowded and antiquated.... By the time the students reach the colleges and universities, it may become a case of getting blood from the proverbial turnip." 1 The implication is that if more money is not forthcoming for more services and more buildings, our libraries will fail in their function of bringing the book and the student together. $O$ tempora! O mores!

Assuming the normal inertia of faculty committees, college administrators, and librarians, this conclusion would appear reasonable. If libraries continue to operate on the principle of bringing the book and the student together by providing "the right book, at the right time, to the right person, in the right spirit" of course their services and routines will break down under greatly increased loads. This type of service ideal has been so ingrained in the library profession and paraded in its textbooks that any other philosophy of librarianship would be heresy. Yet some heretical thinking is exactly what is necessary.

First of all, it is necessary to project

${ }^{1}$ Clifton Brock, "The Rising Tide: Some Implications for College and University Libraries," CRL, XIX (1958), 12-16.

Mr. Land is a Research Consultant in Education, Washington, D. C. From 1937 to 1939 he was Assistant Librarian at Duke University and has since worked on special projects for the Library of Congress. college enrollment data for a considerable period, say"from 1957-58 to 1972-73, and to estimate the nature and force of the variables which may affect that trend in relation to any one institution or group of institutions. In 1956-57, freshman and other first-time college enrollments began to rise steeply. Barring economic or military disasters, they will continue to climb so that in 1972-73, when the curve of population increase will have begun to flatten out, there will be somewhat more than twice as many young people in college as there are now. This does not mean that every college will have twice as many students. For one thing, there will be more institutions, particularly at the two-year junior or community college or vocational technical institute level. The movement to incorporate these institutions as thirteenth and fourteenth grades in the public school system has already begun in some states.

Furthermore, those colleges which appear to have the lowest student costs will attract more undergraduates than those requiring a high level of parental income or a heavy scholarship subsidy. This means that tax-supported institutions will bear the brunt of the student tide. Like the public schools, they will be forced to employ mass teaching methods and to adopt common denominator standards of intellectual achievement. On the other hand, some private colleges will be able to resist overloading and will thus be able to maintain a high qualitative standard of instruction. The less affluent and marginal institutions of all kinds will still find it difficult to fill their classrooms and dormitories. These 
will have to minimize the scope of their curricula and devise other ways of attracting students and balancing institutional budgets. Many variables such as type of college, location, sources of support, student costs, and academic offerings and standards all affect an institution's future outlook. Today, too many institutions are using national projections for local planning without considering thoroughly the possible variable effects of other factors.

It is no heresy to state that successful library activity planning depends on adequate institutional planning. Yet the librarian of a large tax-supported college has said in essence, with reference to his new building, "The dean was busy.... We held no faculty conferences in the early stages. . . The architect read the standard texts, and visited the standard examples." His institution is now saddled with a fine example of library architecture designed for today's pattern of library service even though tomorrow's requirements for mass education may very well be different. As another example, a small church-controlled college located in an increasingly competitive area had accumulated some eighty-thousand volumes over the years. Its fifty-year old library building was truly inadequate. Yet in spite of the penury of its faculty and resources, and without regard to the very high percentage of students majoring in subjects requiring minimum library use, this college raised a substantial sum of money for a new library building to house and expand an outmoded book collection. In both these instances the library will suffer for years to come because of institutional failure in educational planning.

It should not be heresy to suggest that the interwoven problems of book selection, purchase, cataloging, storage, use, retirement, and discard look for their solution to a firm definition of the func- tion which that particular library is to serve in that particular institution. Library activities are generally conducted upon the assumption that any accepted definition is a valid one. In consequence, problems continue to arise and are settled piecemeal because there is insufficient guiding principle. Since the college library is part of an institution devoted to education, its function cannot be defined without firm policy definition and projective planning for the institution as a whole. In this, administrative leadership and responsibility is foremost, but the solution of institutional problems in the educational sphere rests also upon the faculty. With respect to the library, while the responsibility of the college administration is still paramount, leadership in technical matters rests with the librarian and in educational effectiveness with the faculty. Twenty years ago, while still at Lawrence College, president Wriston wrote: "A student does not learn by being told how to use the library, but by using it. Moreover the responsibility for the use of books should not be centered in the librarian, but in the faculty."2 This may be heresy to the library profession, which has gone so far as to say that "competence in the use of the library is one of the liberal arts,"3-a somewhat erratic convolution of that traditional concept. This diversity of attitude indicates that the relationship of the college administration, the faculty and the library technician-however cooperative in meeting immediate problems-needs more of that cohesive quality which arises from common philosophy and educational goal.

Traditionally the library connotes a storehouse of books and a place to study. In seeking library funds a university says,

${ }^{2}$ Henry M. Wriston, The Nature of a Liberal College. (Appleton, Wis., Lawrence College Press, 1937), 65.

${ }^{3}$ Patricia B. Knapp, "A Suggested Program of College Instruction in the Use of the Library," $\mathrm{Li}$ brary Quarterly, XXVI (1956), 230. 
"A new building, imaginatively designed, is a pressing need." Is it too much to ask first for a new imagination on the part of the administration, the faculty, and the librarian before the design becomes pressing? Library plans are being considered in many institutions, each with its own planning and policy decisions to be formulated before spending thousands or millions on cement and steel. In some instances no new building would really be needed, if library activity could pervade dormitories and student unions as well as classroom and laboratory buildings. Without imagination, administrators and trustees blithely assume that library operation is a static concept, and that "the function of the library, and especially of the academic library, is to bring the book and the student together."4 Merely refining or enlarging the present type of library operation will result eventually in faculty and student demands engulfing the library's machinery. It does not take many more students or many years to make a building crowded or antiquated. It does, however, take considerable effort and time to make careful projections of facts and variables for consideration in educational planning, but the result is a creative institutional imagination.

It should not be difficult, for instance, to imagine extending the library's present activities as a supplier of already recorded data-whether in book, journal, film, disc, or machine-coded form-to embrace activities as compiler, manufacturer and distributor where such needs exist. Immediate photo-reproduction of research materials by libraries is becoming a normal expectation. Collections of source materials or selected readings, such as are used experimentally in teaching prior to trade publication, require bibliographical, editorial, reproduction and distribution services which the aca-

Brock, op. cit. demic library is in a position to correlate. The filmed or televised lecture, together with a mass of visual-aid material available from industrial and other sources, can be provided for mass teaching purposes through a library-centered visual aids bureau. Highly successful filmed materials, such as Professor George Boas's lecture, "What Is a Picture?," have been produced under university auspices. Another area requiring centralized technical services is that of the correlation and interpretation of machine-coded information, particularly adaptable to the finite data of the natural sciences, but highly important also to all fields using statistical materials. It may be that publication, visual-aid, statistical, or documentary facilities can be furnished by other divisions of the college or university, but since they involve information seeking, cataloging, or other documentation, and producing materials for research or teaching purposes, the possible usefulness of the library organization within an institution is not to be disregarded. Part of creative institutional planning is to examine these and other possibilities in relation to future research and teaching activities in the light of projected demand, supply, personnel, and financial support.

Possibilities such as these may in practice be envisioned only by already large or still growing instutions with sizeable budgets. Yet small colleges as well as universities can experiment in using the library to extend their educational effectiveness. One method is to bring teaching to the focal point of learning. The majority of American undergraduates find that their need for knowledge becomes pressing at the time when they actually set to work to use library materials on the problems which have been assigned in the classroom. This is the point at which there is the maximum opportunity for stimulating the student's la- 
tent abilities and interests, so that he may work efficiently with the materials at hand and perhaps gradually acquire a concern for the quality and value of his intellectual effort. Using the library may be thought of as having the same relation to studies in the humanities and the social sciences as using the laboratory has to teaching in the physical and biological sciences, even though the work of those laboratories is in turn supplemented by the data recorded in journals and monographs. Thus the teaching function of the college library can be a highly important one.

Since it implements the educational philosophy of the institution itself, such a teaching function of the library is basically the responsibility of the faculty. This implies an organizational division of the library into the two operations of technical processes and of teaching, coordinated by an administrator responsible for financial, educational, and policy liaison with the college administration and the departments of the faculty. It also implies that the less the reference service of the college library represents bibliographical searching or direction of students in library techniques and the more it becomes a guidance of the student's intellectual effort, the type of staff required becomes less that of the libraryscience graduate and more that of the scholar interested in the problems of teaching. Through this teaching function of the college library there is a real opportunity to develop in-service training of seniors or graduate students or young instructors. This is a significant opportunity to nurture a new generation of teachers who will have had experience and insight into the problems of higher education as well as competence in their subject specialties.

In small and large college libraries there is also a pressing need for imaginative experiment in reducing the costs of technical processes. In book selection and purshase, each decision and action involved in the process becomes expensive when multiplied by the number of such actions during the year. Since institutions of similar type and educational philosophy tend to have similar curricula, they ought to be able to combine their selection and ordering operations. This proposal, undoubtedly heretical to both faculty and librarians, is particularly applicable to junior and community colleges which have a relatively consistent level of educational purpose and somewhat limited library funds. It should be possible for such institutions to operate libraries on the package principle of unit standardization. Furthermore, in order to remain within their physical bounds, such libraries could adopt a consistent policy of retiring or discarding library materials. Such college libraries can be operated on the supermarket principle, keeping their stock at a maximum economical level, fresh, and attractive to their customers on primarily a self-service basis. Innovation has been successful in the grocery business: it ought to be tried in college libraries.

No less heretical notions can be developed with respect to cataloging, and it is high time that this expensive technical operation be considered, in college and university libraries, in relation to the teaching function of the library itself. The expansion of reference service into a teaching service, with intellectual and subject competency rather than competency in the use of the library as a goal, implies that there might be much less dependence on the subject entries of the card catalog, which is at best an imperfect and highly variable bibliographic tool. To the extent that the card catalog becomes used as merely a finding list, subject cataloging can be reduced to a finding list of bibliographies. The implications of this suggestion for the li- 
brary budget and for instructional methods in both the library and the classroom deserve careful consideration, particularly in relation to institutional planning.

The heresy of minimal cataloging leads to another, since the fewer records there are to maintain and alter the more chance there is for book collections to become flexible. Minimum inventory and record costs mean that titles can be added and discarded more readily, and the book stock of the college library can be kept abreast of instructional needs without enlarging its storage area. The next step, which professional librarians will surely regard with horror, is to place library collections which are primarily for undergraduate use outside the library's control, letting the student body be completely responsible for inventory and maintenance. Such dormitory or student union collections, or special subject libraries, need not be a drain on the library budget if they are maintained-and lost volumes replaced-from student fee funds. It may be heresy to the administrator who wants every item accounted for at all times, but it is possible that unsupervised library collections, particularly of cheap editions, may be one method of providing a quantity of reading materials, both cultural and instructional, for the rising tide of undergraduates.

It is a commonplace in educational administration that normal practice represents the ideas of two generations ago and that committee decisions are usually a generation removed from the head of the educational procession. Under such circumstances the full tide of college students will have already swamped both library and institution before anything is done to cope with the essentials of the problem and its technical, financial, and educational implications. Solutions arrived at under pressure are likely to be piecemeal, and are likely to engender additional problems. Furthermore, solu- tions which may be satisfactory in one institution may not at all meet the requirements in another situation. Nor is a solution recommended by a "foremost authority" necessarily valid, because he is a "big wheel." It seems to be a characteristic of educators to play follow-theleader, to await the results of a conference, or to let someone else try it first. What is needed is not only creative institutional imagination, but also action based upon projective educational planning.

It is unfashionable today to question the recommendations of nationally organized conferences or committees, particularly in the field of education. It is certainly not surprising that the President's Committee on Education Beyond the High School should include a recommendation that "Federal grants-in-aid on a matching basis be made available ... to assist as many types of nonprofit higher education institutions as possible to construct needed non-income-producing facilities (such as classroom, laboratory, library, and administrative buildings)."5 Yet the history of educational administrators' efforts to obtain Federal money for education at all levels clearly shows that it has become a habit for the American people to look for national aid in solving their common problems. It is, however, very possible that the overhead costs of obtaining Federal aid, together with the additional cost of complying with Federal standards and supervision of plans or construction, increase total costs and delay completion. There are situations in which dependence upon state or Federal cooperative projects, or using governmental funds of any kind, are detrimental to the institution. The college or university library that waits for Federal handouts as a way of solving its problems will merely half-solve them,

\footnotetext{
5 President's Committee on Education Beyond the High School, Second Report to the President (Summary Report, July 1957), 22-23.
} 
for only that which conforms to already accepted patterns will be done. Furthermore, by the time the job gets done the full force of the tidal wave of undergraduates will already have inundated the campus.

It will be objected that any radical experimentation can endanger an institution by the possible withdrawal of regional or professional accreditation. This is merely one of the variables to be considered in educational planning. Assuming that accreditation is of real value to an institution-a view not held by all administrators - its requirements deserve at least diplomatic consideration. It is possible, although not probable, that officials of the little college with an old library of 80,000 volumes could not convince an accrediting group that it would be better to retain only 20,000 volumes chosen so as to benefit its instructional pattern, and to depend on regional resources for the needs of its faculty. In general, accrediting bodies allow for the introduction of experiments which are made on a sound principle, although the initiative in developing new doctrine rests with the institution. Certainly any plan for library resources, facilities, and services which has been formulated as part of an institution's projective planning would more likely be affirmed than otherwise.

Despite impediments to institutional leadership in imaginative educational planning, it is obvious that such leadership is not only essential but that it should be creative. The library is an in- tegral element in whatever steps are taken to cope with instructional problems resulting from the rising tide of student enrollment. The prime need of college and university libraries in relation to the education of undergraduates is not just "a new building, imaginatively designed," but a new design of library operation created through educational creativity and by institutional imagination which values its contribution to the total effectiveness of instruction. Such planning requires not only firm definition of educational policies but also a unity of outlook and coordinated action by college administrator, faculty, and librarian.

We are at the beginning of a new period of rapid growth in college enrollments resulting from the rising tide of American youth of college age. The present trend in educational theory is to provide education or training to whatever extent is required by the ability and willingness of youth to benefit. Thus there are many types of colleges, ranging from overgrown high schools to institutions devoted to the discovery and dissemination of learning. Within these colleges and universities there is ample variation in the educational function which the library may perform. If institutions have not yet considered the library as a potentially important factor in their planning for future educational effectiveness, and if creative imagination has not yet been brought to bear on the problems involved, it is high time for exerting some leadership. And let there be at least a modicum of heresy! 